\title{
Risk Factors of Stunting in Developing Countries: A Scoping Review
}

\author{
Titih Huriah*, Nurjannah Nurjannah \\ Master of Nursing Post Graduate Program, Universitas Muhammadiyah Yogyakarta, Bantul, Yogyakarta, Indonesia
}

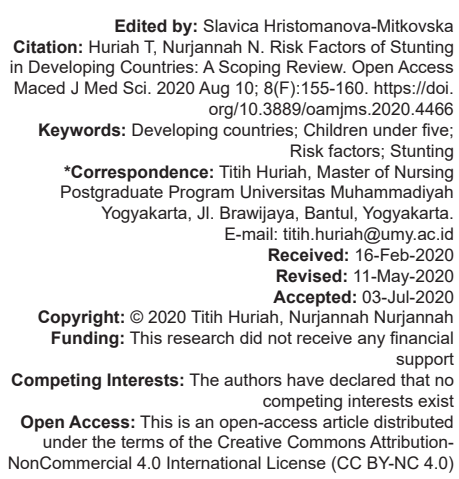
Citation: Huriah T, Nurjannah N. Risk Factors of Stunting in Developing Countries: A Scoping Review. Open Access Maced J Med Sci. 2020 Aug 10; 8(F):155-160. https://do Keywords: Developing countries; Children under five Risk factors; Stunting
*Correspondence: Titih Huriah, Master of Nursing Huriah, Master of Nursing Postgraduate Program Universitas Muhammadiyah Yogyakarta, Jl. Brawijaya, Bantul, Yogyakarta. E-mail: titih.huriah@umy.ac.i Received: $16-\mathrm{Feb}-2020$ Revised: 11-May-2020 Copyright: (๑) 2020 Titih Huriah, Nurjannah Nurianna Funding: This research did not receive any financial Competing Interests: The authors have declared that no competing interests exis Open Access: This is an open-access article distributed under the terms of the Creative Commons Attribution-
NonCommercial 4.0 International License (CC BY-NC 4.0)

\section{Introduction}

Globally, one in four children $(25 \%)$ under 5 years' experience stunting associated with the development and growth retardation. 151 million (22\%) children under the age of five in 2017 experienced stunting, 90\% lived in Sub-Saharan Africa [1], and more than half of them came from Asia [2]. The highest prevalence rate includes Oceania $(38.1 \%)$, Eastern Africa (38.1\%), East Africa (35.6\%), South Asia (33.3\%), and Central Africa (32.1\%).

Data show that $25 \%$ of all stunting children live in low-income countries, $66 \%$ of them live in middleincome countries, and $8 \%$ of them live in high-income countries [3]. The prevalence of stunting declines slowly, with the biggest improvement in Asia and Latin America. However, Africa is the only region where the number of stunted children has increased from $50 \%$ to $59 \%$ between 2000 and 2016. In Ethiopia, a stunting rate reached $40.4 \%$ and was reported in 2015 , with $28 \%$ of children mortality due to malnutrition [4].

The Ministry of Health (2018) stated that stunting problems were experienced by most toddlers in poor and developing countries such as Indonesia. In the world, Indonesia ranked the $17^{\text {th }}$ position of 117 countries.
Indonesia is one of the countries with a high prevalence of stunting compared to other middle-income countries such as Malaysia (20\%) and Thailand (10.5\%) [5], [6]. The WHO data in 2015-2017 stated that Indonesia ranked as the third-highest in the Southeast Asia region with a 36.4\% [7] stunting incident. Based on the result of Riskesdas 2018, it revealed that the nutritional status in Indonesia had been improved with the incidence of stunting reaching $30.8 \%$. The data are still far from the WHO target which is expected to decrease by $20 \%$. Stunting problems that occur in developing countries such as Indonesia will be a public health problem that must be taken seriously and continuously [6].

Stunting is caused by multidimensional factors, not only because of the poor nutritional status of children and pregnant mothers but is due to other factors. Several factors influencing the high stunting prevalence in Indonesia are such as the deficient practice of parenting, limited access to health facility services, including the ANC especially for the pregnant woman's health, limited access to nutritious food for families, as well as limited access to clean water [8]

A number of low and middle-income countries have implemented 14 programs consisting of nutritionspecific programs and nutrition-sensitive programs. The implemented programs, either conducted individually or 
in combination, show different results, where 7 effective programs have been successfully carried out while 7 other programs are still below the Average Annual Rate of Reduction (AARR) [9]. The stunting handling program will be considered effective if the AARR value is $\geq 3 \%$.

Based on the background and some of the factors causing stunting explained above, the authors conducted a scoping review that aims to explore holistically and provide an overview of the risk factors of stunting from various developing countries. It is expected that a comprehensive intervention will be created to reduce the prevalence of stunting in toddlers.

\section{Methods}

The method used is a scoping review using a database of various references such as research journals and journal reviews. A scoping review is such as a reading result from books and scientific journals that provide a clearer picture of how the topic is discussed and understood by previous authors or researchers. Upon the library research, the data collection was conducted, followed by data analysis, interpretation, and report [10].

The data collection process was carried out in December 2019 through the Ebsco, ProQuest, Science Direct, and NCBI databases. The inclusion criteria used for data collection were research articles related to risk factors of stunting in the developing countries, full texted articles, English articles, journal publications in 2015-2019, and the research carried out in developing countries. Exclusion criteria in this review were such as partly accessed publication articles limited to abstracts and books and research articles outside the nursing studies. The searching results were based on inclusion criteria and were analyzed according to the purpose of the review to find out stunting risk factors in developing countries.

The search of the literature was conducted by entering keywords based on research titles such as: "Stunting AND Risk Factors AND Developing Countries." The searching activity found 3605 journals, with the detail of 10 articles from EBSCO databases, 20 articles from ProQuest, 3530 articles from Science Direct, and 45 articles from NCBI. Upon conducting a screening based on the categories of the inclusion criteria, only 9 journals met the criteria. An overview of the process of searching and reviewing the literature can be seen in Figure 1.

Furthermore, the result of the research on the stunting risk factors in Indonesia and other developing countries can be perceived in Table 1.

\section{Results}

This scoping review utilized nine journals whose research was carried out in developing countries such as Indonesia, the Eastern and Western provinces of Rwanda, Northern Ethiopia, Vietnam, the Palestinian Gaza Strip, Bangui (Sub Sahara, Central Africa), South Asia (Dhaka, Bangladesh; Vellore, India; Bhaktapur, Nepal), Latin America (Fortaleza, Brazil, Iquitos, Peru), and Africa (Venda, South Africa; Haydom, Tanzania), East Asia, and the Pacific.

The study of stunting risk factors was associated with the starting of the early life [11], mother's education level[12],[13],[14],[15], children's gender[1],[12], children's age [1], [12], [13], parents' occupation [12], mothers' height [13], [14], [15], [16], [17], neonatal factors and maternal nutritional status [11], [13], [14], [17], inadequate nutrition, children's nutrition and infection [12], [18], mother and parents' relatives with short stature [16], [17], unnoticed sanitation [18], mother's low PMNs and BMI [13], [17], family economic status [12], environmental influence against fetal life [14], fetal growth restriction [18], the duration of weaning process within 6 months or above [12], and social differences [14].

Based on the several journals reviewed above, it is found that the stunting risk factors include (1) parent factors such as neonatal factors and maternal nutritional status during the first 1000 days of children's early life known as HPK, the social differences, mother's education, parents' occupation, and mother's height or parents' relatives with a shorter posture, (2) Children factors such as nutrition, children's infection, the 6-month weaning duration or more, children's gender, and children's age, and (3) environmental factors such as water resources, shared toilets, and environmental influences against fetal life.

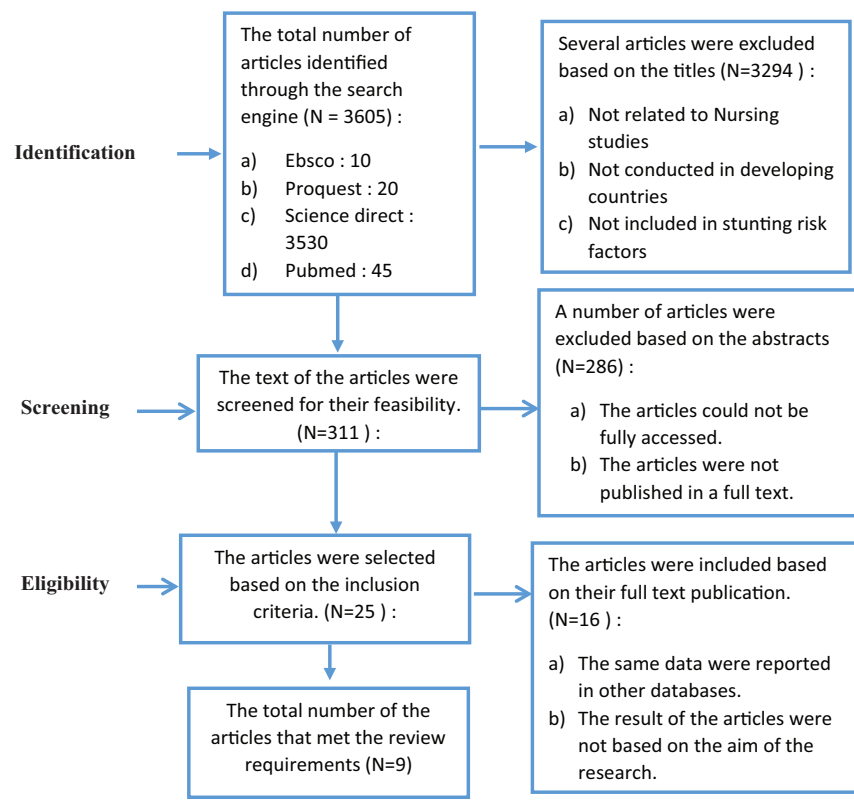

Figure 1: The article searching process 


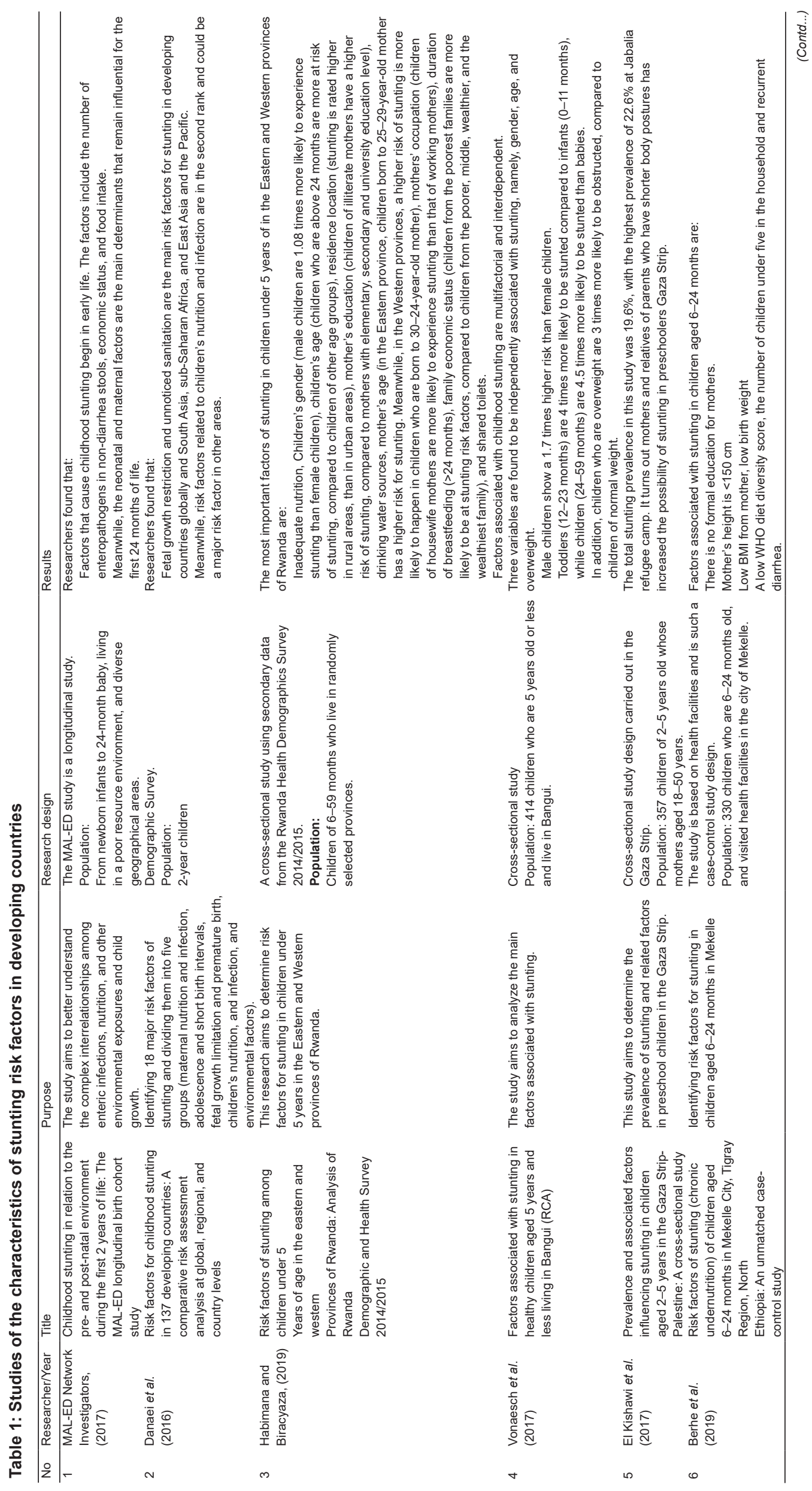

Open Access Maced J Med Sci. 2020 Aug 10; 8(F):155-160. 


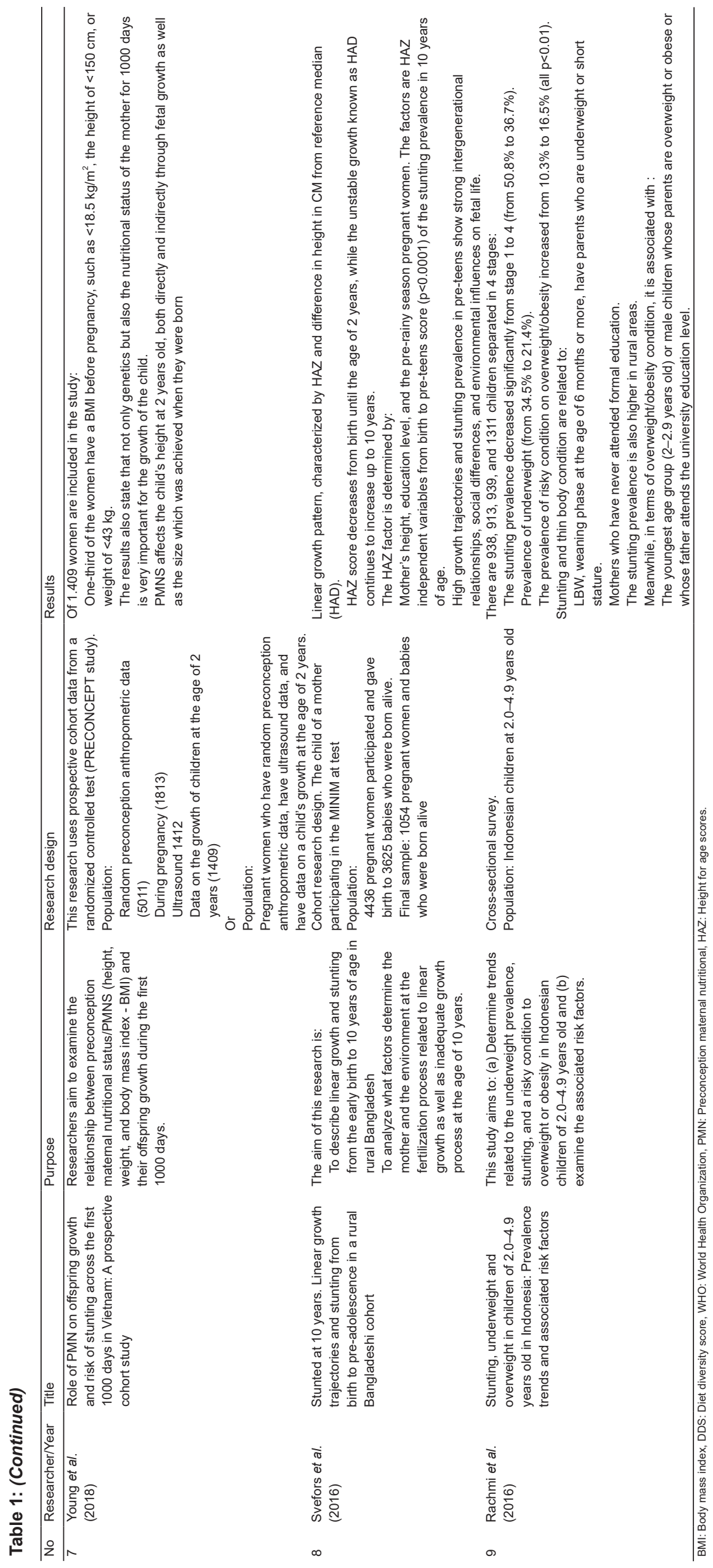




\section{Discussion}

The result of the scoping review shows that there are a number of stunting risk factors in children under 5 years old in developing countries: Parent factors, children's factors, and environmental factors.

\section{The parent factor}

The parent factors consist of maternal nutritional status in the children's 1000 days of early life, social differences, mother's educational level, parents' occupation, and mothers or parents' relatives who have shorter posture. Maternal nutrition plays an important role in fetal growth, infant's health and survival, as well as children's long term health and growth. At the most critical time of early 1000-day life, the mother is the only source of nutrition for infants [17]. Berhe et al. found the same result in their research stating that within the early life period, the children require more adequate nutrients to support their rapid growth and development due to their susceptibility to infection [13].

Family socioeconomic status, such as family income, parent's education level, and parents' occupation, can be indirectly associated with the incidence of stunting. High-income families will more easily gain access to education and health services so that the children's nutritional status can be better developed [19]. The above factors are also supported by research conducted in Northeast Brazil, Myanmar, and Indonesia stating that family income, maternal education level, the short maternal height of $<145 \mathrm{~cm}$, and children's gestational age are found to be risk factors for stunting in children [13].

Although socioeconomic condition plays a role in children's stunting risk factors, the nutritional status, and genetic factors (maternal height, the parents' relatives, and the consanguine relationship) also require careful thought as these factors have been found to be important factors that influence the risk of stunting in the Gaza Strip. In other words, if one or both parents have short posture due to pathological conditions such as growth hormone deficiency, it will increase the opportunity for children to experience stunting [16], [20].

\section{The children factor}

The children factors in stunting include nutrition, children's infectious diseases, weaning process within 6 months or more, children's gender, and children's age. The development of toddlers requires to be monitored so that if an abnormality occurs, it can be detected earlier as the development in infancy determines the future development growth in children. In other words, the basic growth will affect and determine the children's subsequent development.

Complementary foods for breast milk are foods given to babies after the baby is 6 months old which provides additional nutrients other than breast milk. Feeding complementary foods for breast milk in infants should be adjusted to the development of the infants. For example, when the infant learns to chew at the age of 6 or 7 months, they are ready to consume solid food. When solid foods are not given at the time, the baby will experience malnutrition since breast milk or formula milk is no longer able to meet all the nutritional needs of the baby. Conversely, giving complementary foods at an earlier age can cause digestive disorders such as diarrhea, vomiting, and constipation. However, the low complementary foods provision can result in infants having difficulty in learning how to chew, difficulty in consuming solid food, and malnutrition [21].

Stunting more commonly occurs in male toddlers and commonly found in the 36-47-month toddlers [22]. It is supported by the research conducted by Vonaesch et al., revealing that male babies showed a risk of approximately 1.7 times higher in experiencing stunting than female babies [1]. Toddlers (12-23 months) are about 4 times more likely to be stunted compared to infants (0-11 months), while children (24-59 months) are 4.5 times more likely to experience stunting than the babies.

\section{The environmental factor}

The drinking water sources are commonly associated with the physical quality of the drinking water itself. Based on the Regulation of the Minister of Health of the Republic of Indonesia Number 492/MENKES/PER/ $\mathrm{IV} / 2010$ concerning the quality requirements for drinking water, the quality of the drinking water will be considered safe if it meets the physical, microbiological, chemical, and radioactive requirements. The parameters used to identify the good physical quality of the water are when the water is tasteless, odorless, colorless, and not murky. Poor sanitation is also a factor that can cause stunting associated with the possibility of infectious disease. Furthermore, a clean, healthy latrine is a good means for feces disposal to stop the disease dissemination. Latrines that meet the health requirements will be able to preclude the direct spread and can prevent diseasecarrying vectors in latrine users and the surrounding environment [23].

The poor quality of sanitation is revealed to be the major risk factor for stunting in developing countries globally either in South Asia, sub-Saharan Africa, and East Asia and the Pacific. Thus, a healthy environment, including water, sanitation, and good hygiene practices, needs careful thought [4],[18]. 


\section{Conclusion}

This scoping review revealed that risk factors for stunting in developing countries could be divided into three categories: (1) The parental factors (neonatal factors and maternal nutritional status at the early 1000 days of birth, social differences, mother's education level, parent's occupation, and the height of mother or parent's relatives with short posture, (2) the children factors (nutrition, children's infection, the weaning process within 6 months or more, children's gender, and children's age), and (3) the environmental factors (water sources, shared toilets, and environmental influences on fetal life).

\section{References}

1. Vonaesch P, Tondeur L, Breurec S, Bata P, Nguyen LB, Frank T, et al. Factors associated with stunting in healthy children aged 5 years and less living in Bangui (RCA). PLoS One. 2017;12(8):e0182363. https://doi.org/10.1371/journal.pone.0182363 PMid:28796794

2. Titaley CR, Ariawan I, Hapsari D, Muasyaroh A, Dibley MJ. Determinants of the stunting of children under two years old in Indonesia: A multilevel analysis of the 2013 Indonesia basic health survey. Nutrients. 2019;11(5):1106. https://doi. org/10.3390/nu11051106

PMid:31109058

3. Purwanti R, Nurfita D, Soedarto JH, Soepomo JD. Review literatur: Analisis determinan sosio demografi kejadian stunting pada balita di berbagai Negara Berkembang. Bul Penelit Kesehat. 2019;47(3):12. https://doi.org/10.22435/bpk.v47i3.1349

4. Kwami CS, Godfrey S, Gavilan H, Lakhanpaul M, Parikh P. Water, sanitation, and hygiene: Linkages with stunting in rural Ethiopia. Int J Environ Res Public Health. 2019;16(20):3793. https://doi.org/10.3390/ijerph16203793 PMid:31600942

5. Pratiwi SR. Manajemen Kampanye Komunikasi Kesehatan Dalam Upaya Pengurangan Prevalensi Balita Stunting. J Manajemen Komunikasi. 2019:4(1):82. https://doi.org/10.24198/ jmk.v4i1.23435.

6. Budiastutik I, Rahfiludin MZ. Faktor risiko stunting pada anak di Negara Berkembang. Amerta Nutr. 2019;3(3):122. https://doi. org/10.20473/amnt.v3i3.2019.122-129

7. Pusat Data dan Informasi. Situasi Balita Pendek (Stunting) di Indonesia. Buletin Jendela Data dan Informasi Kesehatan. Kesehatan: Kementerian Kesehatan RI; 2018.

8. Tim Nasional Percepatan Penanggulang Kemiskinan. 100 Kabupaten/Kota Prioritas Untuk Intervensi Anak Kerdil (Stunting). Jakarta, Indonesia: Sekretariat Wakil Presiden RI; 2017.

9. Hossain M, Choudhury N, Abdullah KA, Mondal P, Jackson AA, Walson J. Evidence-based approaches to childhood stunting in low and middle income countries: A systematic review. Arch Dis Child. 2017;102(10):903-9. https://doi.org/10.1136/ archdischild-2016-311050 PMid:28468870

10. Jozef R. Metode Penelitian Kualitatif. Jakarta: PT. Gramedia Widia Sarana Indonesia; 2010.

11. MAL-ED Network Investigators. Childhood stunting in relation to the pre-and postnatal environment during the first 2 years of life: The MAL-ED longitudinal birth cohort study. PLoS Med. 2017;14(10):e1002408. https://doi.org/10.1371/journal. pmed.1002408

PMid:29069076

12. Habimana S, Biracyaza E. Risk factors of stunting among children under 5 years of age in the eastern and Western provinces of Rwanda: Analysis of Rwanda demographic and health survey 2014/2015. Pediatr Health Med Ther. 2019;10:115-30. https:// doi.org/10.2139/ssrn.3379825 PMid:31695558

13. Berhe K, Seid O, Gebremariam Y, BerheA, Etsay N. Risk factors of stunting (chronic undernutrition) of children aged 6 to 24 months in Mekelle city, Tigray Region, North Ethiopia: An unmatched case-control study. PLoS One. 2019;14(6):e0217736. https:// doi.org/10.1371/journal.pone.0217736 PMid:31181094

14. Svefors $P$, Rahman $A$, Ekström EC, Khan Al, Lindström $E$, Persson $L A$, et al. Stunted at 10 years. Linear growth trajectories and stunting from birth to pre-adolescence in a rural Bangladeshi cohort. PLoS One. 2016;11(3):e0149700. https:// doi.org/10.1371/journal.pone. 0149700 PMid:26934484

15. Rachmi CN, Agho KE, Li M, Baur LA. Stunting, underweight and overweight in children aged 2.0-4.9 years in Indonesia: Prevalence trends and associated risk factors. PLoS One. 2016;11(5):e0154756. https://doi.org/10.1371/journal. pone. 0154756

PMid:27167973

16. El Kishawi RR, Soo KL, Abed YA, Muda WA. Prevalence and associated factors influencing stunting in children aged 2-5 years in the Gaza Strip-Palestine: A cross-sectional study. BMC Pediatr. 2017;17(1):210. https://doi.org/10.1186/ s12887-017-0957-y

PMid:29268788

17. Young MF, Nguyen PH, Casanova IG, Addo OY, Tran LM, Nguyen S, et al. Role of maternal preconception nutrition on offspring growth and risk of stunting across the first 1000 days in Vietnam: A prospective cohort study. PLoS One. 2018;13(8):e0203201. https://doi.org/10.1371/journal.pone.0203201 PMid:30161206

18. Danaei G, Andrews KG, Sudfeld CR, Fink G, McCoy DC, Peet E. Risk factors for childhood stunting in 137 developing countries: A comparative risk assessment analysis at global, regional, and country levels. PLoS Med. 2016;13(11):e1002164. https://doi. org/10.1371/journal.pmed.1002164 PMid:27802277

19. Ni'Mah K, Nadhiroh SR. Faktor yang berhubungan dengan kejadian stunting pada balita. Med Gizi Indones. 2016;10(1):13-9. https://doi.org/10.31227/osf.io/d6pmq

20. Yanti R, Nova M. Kejadian stunting balita usia 24-36 bulan. $J$ Nutr Coll. 2019;10:6.

21. Angkat $\mathrm{AH}$. Penyakit infeksi dan praktek pemberian MP-AS terhadap kejadian stunting pada anak usia 12-36 Bulan di Kecamatan Simpang kiri kota subulussalam. J Dunia Gizi. 2018;1(1):52. https://doi.org/10.33085/jdg.v1i1.2919

22. Damayanti RA, Muniroh L, Farapti F. Perbedaan tingkat kecukupan zat gizi dan riwayat pemberian asi eksklusif pada balita stunting dan non stunting. Med Gizi Indones. 2017;11(1):61-9. https://doi.org/10.20473/mgi.v11i1.61-69

23. Sinatrya AK, Muniroh L. Hubungan faktor water, sanitation, and hygiene (WASH) dengan stunting di wilayah Kerja Puskesmas Kotakulon, kabupaten Bondowoso. Amerta Nutr. 2019;3(3):164. https://doi.org/10.20473/amnt.v3i3.2019.164-170 